\title{
Short Note \\ Late Ordovician-Silurian orthoconic nautiloid cephalopods in the View Point Formation conglomerate, Antarctic Peninsula
}

\author{
ALAN P.M. VAUGHAN ${ }^{1}$, CHARLES H. HOLLAND ${ }^{2}$, JOHN D. BRADSHAW ${ }^{3}$ and MICHAEL R.A. THOMSON ${ }^{4}$ \\ ${ }^{I}$ British Antarctic Survey, NERC, High Cross, Madingley Road, Cambridge CB3 OET, UK \\ ${ }^{2}$ Department of Geology, Trinity College, Dublin 2, Ireland \\ ${ }^{3}$ Department of Geological Sciences, University of Canterbury, Private Bag 4800, Christchurch 8140, New Zealand \\ ${ }^{4}$ Centre for Polar Sciences, School of Earth Sciences, University of Leeds, Leeds LS2 9JT, UK
}

a.vaughan@bas.ac.uk

Received 12 April 2012, accepted 11 July 2012, first published online 13 August 2012

\section{Introduction}

The Trinity Peninsula Group at View Point, northern Antarctic Peninsula comprises a succession of thin sandstone-mudstone couplets of probably turbidity current origin (Bradshaw et al. 2012). This succession, which is southward younging and overturned, hosts $100 \mathrm{~m}$-thick sequences of lenticular sandstone bodies, at least ten of which include pebble to boulder conglomerates up to $15 \mathrm{~m}$ thick. The deposits are probably of submarine fan origin and it is thought that the thick lenticular sequences (with boulders up to $1.3 \mathrm{~m}$ ) are derived from contemporary or slightly older PermoCarboniferous glaciomarine sediments. U-Pb zircon geochronology points to a depositional age of c. $302 \mathrm{Ma}$. The conglomerate clasts are mainly quartzite and granite but rare sandstone clasts contain poorly preserved invertebrate fossils, mainly indeterminate nuculoid bivalves. Two sandstone cobble clasts from different localities (BAS station DJ.1318 - $63.5518^{\circ} \mathrm{S}, 057.4014^{\circ} \mathrm{W}$, altitude $144 \mathrm{~m}$, and BAS Station DJ.1337 - $63.5511^{\circ} \mathrm{S}, 057.4616^{\circ} \mathrm{W}$, altitude $204 \mathrm{~m}$ ) contain orthoconic nautiloid cephalopods. Although the material is of relatively poor quality and preservation, given the rarity of orthocone material from Antarctica it merits formal record.

\section{Fossil material}

Two specimens of fine-grained, laminated sandstone, forming cobble clasts in conglomerate from the View Point Formation of the Trinity Peninsula Group, each yield a poorly preserved portion of an internal mould of an orthoconic nautiloid cephalopod (Sweet 1964). Specimen DJ.1318.1 (Fig. 1) shows a longitudinal section about $20 \mathrm{~mm}$ long whose diameter ranges from $6 \mathrm{~mm}$ about the middle to $8 \mathrm{~mm}$ adorally. About 15 septa are relatively closely spaced, at only about $2 \mathrm{~mm}$ apart. Where seen on the broken surface, they appear to be direct and with only slight concavity. The septa and a portion of the shell wall appear as partly infilled hollows. The camerae are packed with non-calcareous crystalline material, probably quartz.

The second specimen (DJ.1337.1) is a smooth, threedimensional mould about $18 \mathrm{~mm}$ long with a maximum preserved diameter of about $9 \times 10 \mathrm{~mm}$ (Fig. 2a). A convex septal surface is preserved at the adapical end with depth of $0.5 \mathrm{~mm}$ (Fig. 2b). A very small siphuncle, only about $1 \mathrm{~mm}$ in diameter, is seen approximately centrally (Fig. 2b).

\section{Interpretation}

In the absence of information on ornamentation or internal structure, both of which figure so prominently in nautiloid taxonomy, it is difficult to identify this material, but it is reasonable to suppose that the two specimens represent the same taxon. The small size and simple orthoconic morphology, with closely spaced septa and centrally placed small siphuncle, are indicative of the great generalized Order Orthocerida (Kuhn, 1940) and its Family Orthoceratidae (McCoy, 1844) within that part of its range which extends from upper Ordovician to Silurian (Sweet 1964). An echinoderm columnal seen at the adoral end of the longitudinal section in specimen DJ.1318.1 (Fig. 1) is unhelpful in age assignment. An upper Ordovician-Silurian age for the specimens is indicated.

\section{Discussion}

Orthoconic nautiloid cephalopods from Antarctica are extremely rare. They have only been recorded from two localities previously. Webers et al. (1992) recorded

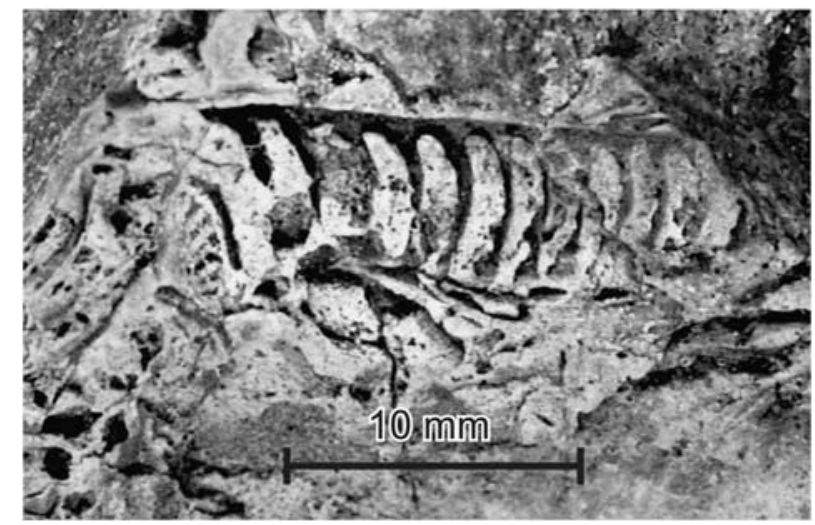

Fig. 1. Specimen DJ.1318.1 showing longitudinal section. 

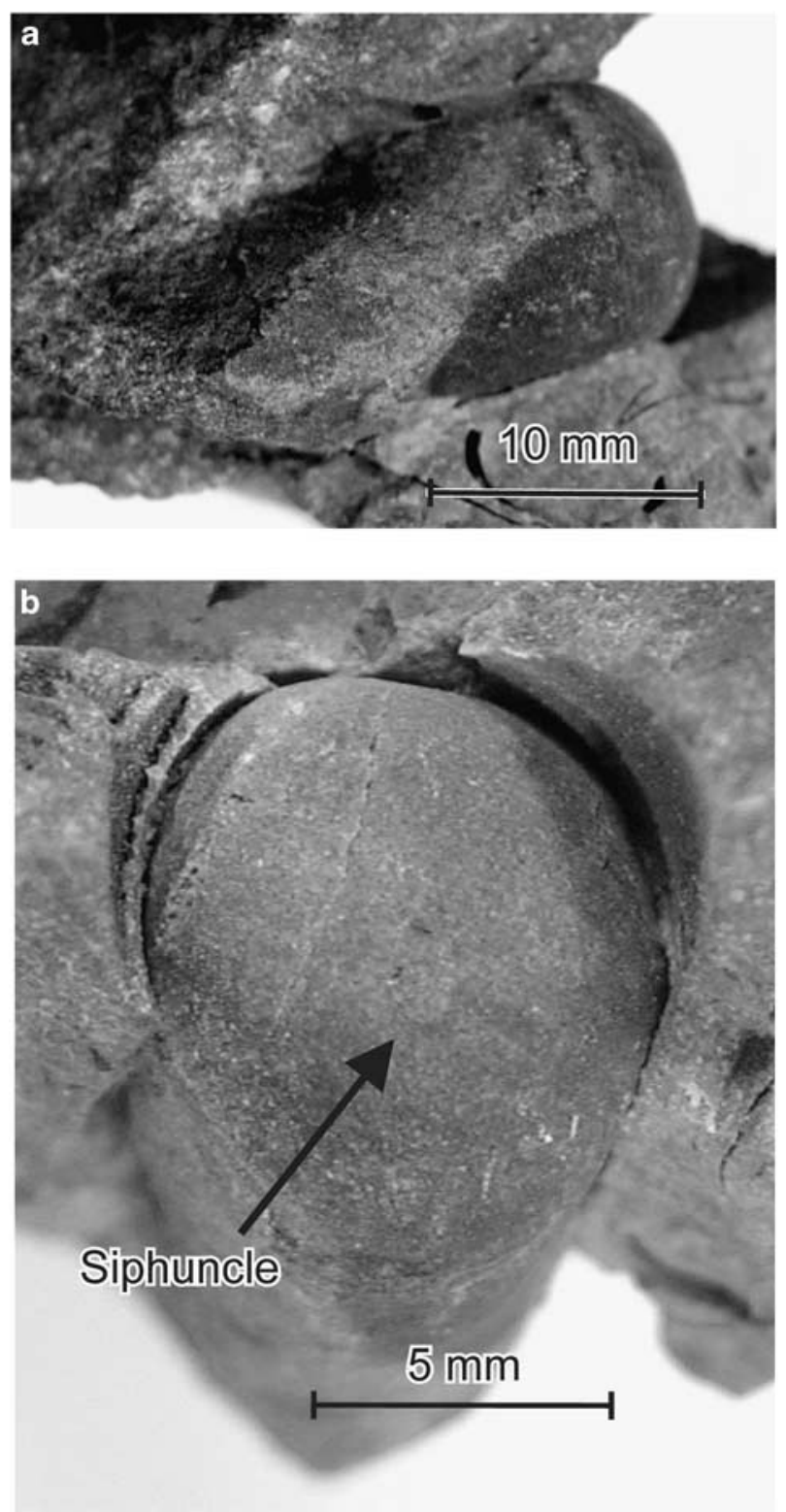

Fig. 2. Specimen DJ.1337.1 showing a. longitudinal view, and b. adapical view with siphuncle indicated.

indeterminate cephalopods of the Order Orthocerida from the Lower Devonian Mount Wyatt Earp Formation of the Crashsite Group of the Ellsworth Mountains. Kelly et al. (2001) recorded an "undetermined orthocone" from Carboniferous limestones of the Mount King beds on Alexander Island in the Antarctic Peninsula. Of additional note is that the age assignment of the fossil material dates the sedimentary rocks forming the enclosing cobble clasts as late Ordovician-Silurian. Sedimentary rocks of Silurian age have not previously been identified in Antarctica. Detrital zircon data from the sedimentary rocks of the View Point Formation also do not reflect this age range, showing two earlier Palaeozoic peaks: early to mid-Ordovician and late Devonian (Bradshaw et al. 2012). Zircon geochronology indicates potential southern South American or East Antarctica/southern Africa provenance for the View Point Formation conglomerate, but zircon hafnium isotope data weigh strongly in favour of an Ellsworth-Whitmore mountains block source (Bradshaw et al. 2012). Nevertheless, the diamictic nature of the enclosing conglomerate does not preclude more distal derivation in Gondwana of the orthoconebearing clasts. If an Ellsworth-Whitmore mountains block source is considered, then derivation of the orthocone-bearing cobbles is most probably from rocks comparable to the lower part of the 3000 m-thick Cambrian-Permian Crashsite Group, which, although unconfirmed, has been suggested to be Ordovician-Silurian (Spörli 1992).

\section{Acknowledgements}

This work was funded by NERC British Antarctic Survey core funds as part of the Polar Science for Planet Earth programme. The authors would like to thank an anonymous reviewer and the editor. The authors thank the captain, crew and helicopter pilots of HMS Endurance and BAS Operations staff for their cooperation and assistance with logistics.

\section{References}

Bradshaw, J.D., Vaughan, A.P.M., Millar, I.L., Flowerdew, M.J., Trouw, R.A.J., Fanning, C.M. \& Whitehouse, M.J. 2012. PermoCarboniferous conglomerates in the Trinity Peninsula Group at View Point, Antarctic Peninsula: sedimentology, geochronology and isotope evidence for provenance and tectonic setting in Gondwana. Geological Magazine, 149, 626-644.

Kelly, S.R.A., Doubleday, P.A., Brunton, C.H.C., Dickins, J.M., Sevastopulo, G.D. \& Taylor, P.D. 2001. First Carboniferous and ?Permian marine macrofaunas from Antarctica and their tectonic implications. Journal of the Geological Society, 158, 219-232.

SPÖRLI, K.B. 1992. Stratigraphy of the Crashsite Group, Ellsworth Mountains, West Antarctica. In Webers, G.F., Craddock, C. \& Splettstoesser, J.F., eds. Geology and palaeontology of the Ellsworth Mountains, West Antarctica. Geological Society of America Memoirs, 170, 21-36.

SweEt, W.C. 1964. Nautiloidea-Orthocerida. In Moore, R.C., ed. Mollusca 3. Treatise on invertebrate paleontology, Part K. Lawrence, KS: Geological Society of America and University of Kansas Press, 216-261.

Webers, G.F., Glenister, B., Pojeta Jr, J. \& Young, G. 1992. Devonian fossils from the Ellsworth Mountains, West Antarctica. In Webers, G.F., Craddock, C. \& Splettstoesser, J.F., eds. Geology and palaeontology of the Ellsworth Mountains, West Antarctica. Geological Society of America Memoirs, 170, 269-278. 